\title{
HACIA UN PLANTEAMIENTO SEMIÓTICO DEL ESTEREOTIPO PUBLICITARIO DE GÉNERO
}

\author{
Susana DE ANDRÉS DEL CAMPO \\ Universidad de Valladolid \\ delcampo@hmca.uva.es
}

Resumen: Las visiones estereotipadas de los grupos sociales se alojan y estructuran en el mensaje publicitario a través de las distintas codificaciones del mismo. En este artículo se sugiere un estudio sintáctico de los estereotipos de género que aparecen en los anuncios gráficos, a partir de la semiótica de la publicidad.

Abstract: A stereotyped view of social groups is lodged and structured in advertising messages. This article suggests a syntactic study of gender stereotypes as they appear in graphic advertisements, following Semiotics.

Palabras clave: Semiótica. Publicidad. Estereotipos de género.

Key words: Semiotics. Advertising. Gender stereotypes. 
Los mensajes publicitarios transmiten, en ocasiones, visiones estereotipadas de los grupos sociales. El estudio de los estereotipos se ha realizado a menudo desde la psicología y la sociología, pero la plasmación en los mensajes publicitarios de estas construcciones cognitivas merece una observación desde el prisma de la semiótica.

Se ha considerado que la publicidad es un lenguaje, en la medida en que constituye una sustitución semiótica de la realidad. Según el doctor en Linguiística, Juan Antonio González Martín (1982: 51), la publicidad posee la naturaleza de un sistema propio de comunicación, caracterizado por su función denominativa, predicativa y afirmativa. Este lenguaje publicitario parece constar de una gramática que responde a las reglas de la semiótica ${ }^{1}$. En este marco del lenguaje, el estereotipo que se introduce en el mensaje publicitario - aquel que podemos denominar estereotipo publicitario - se plasma a partir de diferentes signos, susceptibles de ser analizados desde la semiótica.

Mediante el uso de elementos semióticos, la publicidad representa y sustituye la propia realidad de los objetos y también de los sujetos. La representación publicitaria de un grupo de personas es una sustitución semiótica de las mismas, identificable en la medida en que constituye una convención perceptiva.

El mensaje publicitario está abierto a su contexto y es esta permeabilidad lo que le lleva a reflejar los estereotipos sociales. Absorbido el estereotipo social, éste se articula gramaticalmente en el mensaje publicitario, deja de ser construcción mental y se convierte en signo lingüístico. Juan Antonio González Martín (1996: 234) explica que el mensaje publicitario es un sistema abierto a la significación, es decir, a la conversión de los objetos en signos; y que si bien el gran signo del mensaje publicitario es el producto anunciado, otros elementos se articulan de forma sígnica para conferir significado al producto.

El caso de los estereotipos publicitarios de grupos sociales es una muestra de que el lenguaje publicitario también convierte en signo a la persona. Las representaciones publicitarias de las personas trascienden la mera referencialidad. El modelo retratado pasa a constituir un referente de todo un grupo social (amas de casa, ejecutivos, adolescentes, varones urbanos de clase alta, etc.). En ese proceso, la persona representada se carga de significación y se convierte así en signo.

${ }^{1}$ Como explica Raúl Eguizábal (1990: 7): «Y es que solamente dentro de la semiótica puede precisarse una noción específica de lenguaje acorde con la comunicación publicitaria». 


\section{EL ESTEREOTIPO PUBLICITARIO COMO PROCESO DE SIM- BOLIZACIÓN}

El estereotipo publicitario puede filtrarse en el mensaje publicitario transformándose en signos, pero ¿qué tipo de signos? Las figuras de personas retratadas en los anuncios responden a una estructura visual representacional, aunque, cuando son tratadas de forma estereotipada, puede afirmarse que la estructura es simbólica. Según González Martín (1990, p. 65) la función simbólica consiste en «[...] poder dar a una idea una representación, haciendo que dicha representación funcione como un signo»; ese nivel simbólico «[...] se genera sobre un grado de convención y se refiere a una determinada realidad manipulada y arbitraria.» (González Martín, 1982: 179). Cuando la imagen funciona como estereotipo, entonces es convención. La imagen estereotipada de una mujer, por ejemplo, no puede explicarse mediante la iconicidad, porque no trata de presentar a una persona con nombres y apellidos, de hecho no importa si existe o no esa persona. Lo que se pretende es simbolizar en esa imagen un concepto social imperante sobre el grupo social de las mujeres y, por tanto, sobre la feminidad. En unos casos, la imagen será símbolo de elegancia, belleza o dulzura; en otros, de misterio, seducción o erotismo, etc. En ese nivel se produce la simbología.

Para Peirce (1986: 57) el símbolo es un signo convencional o dependiente de un hábito. De igual manera, el estereotipo publicitario es convención y rutina, concierto y vicio creativos. Entendido el estereotipo publicitario como símbolo, el signo es la representación publicitaria, lo que recibe aquí el nombre de estereotipo publicitario; lo denotado será la persona y lo connotado será el significado del símbolo. La interpretación del destinatario es la que le otorga sentido con sus creencias sobre el grupo social que representa. Donde hay estereotipo hay interpretación subjetiva, de ahí su definición como representaciones mentales. En el caso de la simbolización, el signo se relaciona con el objeto sólo por mediación del interpretante:

El símbolo es por tanto un ejemplo claro de relación triádica genuina, puesto que es una relación conjunta del vehículo del signo (medio), la cosa denotada (objeto) y la mente (interpretante) (González Martín, 1982: 193).

El grupo social estereotipado pertenece al mundo de la realidad social, el signo publicitario pertenece al lenguaje publicitario y la interpretación del mismo se produce a un nivel psicológico. Esta relación sociología / realidad social; lenguaje / publicidad; psicología / mente integra tres naturalezas y al 
menos tres disciplinas, lo que hace difícil explicar los procesos de construcción y comunicación del estereotipo publicitario tanto como de las plasmaciones del estereotipo social en otros lenguajes de diversa naturaleza como el arte, la literatura o la música, por citar otros marcos de estereotipia.

La clásica relación entre objeto, medio e interpretante es aplicable al caso del estereotipo publicitario. El objeto es el grupo social sobre el que se estereotipa, el medio es la publicidad y el interpretante, el lector del anuncio. En esta relación triádica no importa tanto la relación entre objeto y medio como la relación entre medio e interpretante, porque es el interpretante quien reconoce el estereotipo representado en la publicidad y lo confronta con el estereotipo cognitivo al que se asemeja.

La idea de la categorización como símbolo fue apuntada por González Martín (1990: 65) cuando afirmó, tratando el tema de la publicidad política, que todo uso simbólico deriva en una categorización, lo que explicó de la siguiente manera:

El símbolo se sitúa entre el pensamiento y el lenguaje, posibilitando una categorización de la realidad, que no ofrecen el resto de recursos semánticos a los que acude la publicidad política.

El símbolo, como el estereotipo ${ }^{2}$, permite una categorización de la realidad y nunca se refiere a lo individual, sino a clases generales. Es una modalidad puramente semiótica.

\section{LA CONSTRUCCIÓN SINTÁCTICA DEL ESTEREOTIPO PU- BLICITARIO DE GÉNERO}

El estereotipo publicitario tiene forma, significado e intención; por ello, es susceptible de ser estudiado desde los tres ámbitos de la gramática — sintaxis, semántica y pragmática—, como se sugiere a continuación.

2 Otro estudio viene a afirmar también que las representaciones de las personas en la publicidad son, en realidad, símbolos: «[...] en la publicidad no encontraremos seres reales, sino categorías sociales simbolizadas en los personajes publicitarios...» (León, 2001: 83). No obstante, José Luis León considera que esta simbolización es un tipo de mito, más que de estereotipo. 


\subsection{Sintaxis}

El estereotipo publicitario es a la vez representación y valoración, y en el mensaje publicitario se expresa, no sólo con la mera representación de personas de un grupo social estereotipado, sino a través de toda una sintagmática. El ámbito de referencia de la sintagmática es la codificación, mientras que su objetivo es la articulación (González Martín, 1996: 234). Es a través de la sintagmática como puede elaborarse un análisis del proceso de construcción del estereotipo publicitario. La valoración y el significado con que se carga el estereotipo publicitario son insertados a través de la compleja codificación del mensaje publicitario, como más adelante se ejemplifica.

\subsection{Semántica}

El universo semántico de la publicidad es cerrado y previsible (op. cit.: 239) y entre lo previsible se encuentra lo estereotipado. Los mensajes son redundantes entre sí y la mayoría suele convenir una visión estándar del mundo, tal como la proporciona el estereotipo. En este sentido, la semántica del lenguaje publicitario está abierta al estereotipo. En efecto, diversas figuras retóricas de común uso publicitario se utilizan con fines estereotipadores, como ocurre en los ejemplos que acompañan el artículo.

\subsection{Pragmática}

La comunicación publicitaria tiene que recurrir a convenciones y simplificaciones de la realidad para asegurar su decodificación y cumplir así con su imperativo de eficacia. En este sentido, la estereotipia es un recurso de amplia y justificada utilización por parte de los anuncios. La misma lógica de la publicidad como comunicación dirigida a una gran cantidad de gente hace casi inevitable el recurso a la estereotipia.

El mensaje publicitario ha de calar en su destinatario y para ello necesita ser comprensible. Los estereotipos publicitarios tienen como función simplificar la realidad y facilitan la comprensión de los mensajes, es decir, vienen determinados por una función pragmática. El principio de economía del mensaje de la publicidad, su pragmatismo y la naturaleza de su audiencia son algunas de las razones que explican el recurso continuado del estereotipo en el mensaje publicitario. 


\section{ESTUDIO SINTÁCTICO DEL ESTEREOTIPO PUBLICITARIO}

Indicados los tres componentes gramaticales y cómo cada uno de ellos suscitaría un abordaje posible del estereotipo publicitario, se dedica ahora atención más detallada al estudio formal del mismo, si bien se trata sólo de sugerir la posibilidad del estudio semiótico del estereotipo publicitario de género.

Un estudio sintáctico del estereotipo publicitario proporciona las pautas de lectura de los mismos y muestra la lógica de su plasmación en los anuncios.

Respecto al estudio formal de cómo el estereotipo publicitario utiliza recursos sintácticos para construirse en los anuncios, se descubre que es susceptible de ser transmitido a través de todos los códigos del lenguaje de la publicidad, por tanto su articulación puede ser compleja o muy simple, pudiendo quedar transmitido por todo el conjunto de codificaciones en un mismo anuncio, o bien por medio de un código concreto.

\subsection{Codificación verbal}

El lenguaje verbal no es neutro, sino que se pronuncia sobre las diferencias entre hombres y mujeres. Otros estudios, por ejemplo el de Aguas Vivas et. al. (1995), ya lo han analizado y demostrado. Lo mismo ocurre con el código verbal publicitario.

En muchos anuncios se incluyen referencias verbales a distintos grupos sociales que transmiten claramente visiones estereotipadas de los mismos. La referencia verbal es explícita, por eso es fácil identificar el estereotipo transmitido mediante este código. La frase, tanto como la palabra, puede ser estereotipadora. La entonación o figuras, como la hipérbole o el símil, pueden servir a la estereotipia igualmente.

\subsubsection{La frase publicitaria}

La estereotipia suele ser evidente si se realiza a través de una frase. El siguiente titular del anuncio de Philishave puede servir de ejemplo: las Philishave son como las novias. Si no las amas después de tres semanas, deshazte de ellas. Dentro de las muchas oraciones que pueden encontrarse en los textos de los anuncios, dos tipos son especialmente abundantes y particularmente estereotipadoras: las frases tópicas y los eslóganes. 
Respecto a las frases tópicas, como explica González Martín (1996: 238) «En comunicación publicitaria se descarta todo aquello que no ayude a un desarrollo preciso del tópico textual». El tópico invade la publicidad. En un spot de la marca de telefonía MoviLine, la voz en off comenzaba: todos los españoles son toreros,... Las guapas son tontas. En los anuncios, como en tantos otros discursos, se opina sobre los conocidos tópicos respecto a grupos sociales distintos, si bien en el ejemplo indicado el tópico se introduce para después desmentirlo.

Por su parte, el eslogan es el recurso verbal de mayor carga semántica dentro del texto publicitario. La simplicidad en su articulación, la simplificación a la que recurre y la carga de significado que transporta lo convierten en vehículo frecuente de estereotipia. Pueden recordarse eslóganes controvertidos precisamente por lo estereotipado de su visión de la mujer o del hombre. Toda tú eres un culito, fue una frase elegida por Calber en 1982, ampliamente criticada por su tratamiento sexista de la mujer. Soberano es cosa de hombres, indicaba con gran fuerza lo que es propio e impropio de cada género.

\subsubsection{La palabra en la publicidad}

Sin recurrir a la frase, la estereotipia puede colarse en la publicidad, valiéndose de la sola palabra. En sí misma, no puede decirse que una palabra pueda ser estereotipadora, ya que lo que le otorga esta cualidad es el uso de la misma que realiza quien la enuncia. La adscripción especialmente frecuente tanto como la especialmente infrecuente de adjetivos, denominaciones o acciones a distintos grupos sociales puede constituirse en signo de estereotipia.

Las palabras que pueden transmitir estereotipia son las palabras plenas, es decir, las que contienen significante y significado. Palabras plenas son los sustantivos, los adjetivos, los verbos y los adverbios. Por su parte, las palabras instrumento, al servir como unidades relacionantes, no son transportadoras de estereotipos por sí solas.

Quien narra, también interpreta. Por ello, en la narración publicitaria, sea oral o escrita, se realizan interpretaciones estereotipadas de los grupos sociales. Al estereotipar, ese lenguaje se encola de una cierta emoción por parte del emisor que esperará compartir con el receptor. Como dice Ferrer (1994: 65): «La palabra, reina del lenguaje publicitario, refleja no sólo la noción de la cosa - caudal informativo - , sino el sabor de ella — caudal emocional—, entre lo que esa cosa es y lo que parece ser; del significado a la sugestión». 
Algunos significados otorgados a los sustantivos son en sí mismos estereotipadores de los géneros. Por poner uno de los ejemplos más evidentes, el Diccionario de la Real Academia de la Lengua Española (1992: 1117) define hombre como «Ser animado racional. Bajo esta acepción se comprende todo el género humano. 2. Varón, criatura racional de sexo masculino». En contraposición, mujer queda definido como «Persona del sexo femenino. 2. La que ha llegado a la edad de la pubertad. 3. La casada, con relación al marido» (op. cit.: 1414). Entre las locuciones indicadas en las definiciones se incluyen, dentro de las de hombre, algunas como hombre bueno, hombre de armas, hombre de buenas letras, hombre de cabeza, hombre de ciencia, hombre de corazón, hombre de dinero, hombre de distinción, hombre de Estado... Muy al contrario, todas las locuciones incluidas en la definición de mujer son, en este orden: mujer de digo y hago, de edad, de gobierno (criada), del arte, del partido, de mala vida, de mal vivir, o de punto. Ramera. De su casa. Fatal. Mayor. Mundana, perdida, o pública. Ramera. Locuciones éstas escasas, repetitivas, estereotipadoras y reduccionistas de la condición femenina. Entre quince locuciones, ocho se refieren a la prostituta.

Pero no es éste ningún alegato feminista ni tampoco una denuncia. Sólo un ejemplo para explicar que el uso de las palabras y la semántica que se les asigna lleva carga estereotipadora y, por tanto, el uso publicitario de las mismas caerá en la misma valoración de manera inevitable.

Por otra parte, no sólo estereotipa la carga semántica de las palabras o el uso de las mismas. La inexistencia de palabras para designar ciertos rasgos, cualidades, oficios, etc. para el caso de hombres o mujeres, también es un indicador de estereotipia social. El mismo ejemplo de la palabra marido, diferente a la de hombre, no tiene parangón para el caso femenino. Con esa misma lógica, conceptos o palabras como Intuition (Stēe Lauder) o Flower (Kenzo) son nombres de perfumes femeninos, mientras que Adventure (Jesús del Pozo) o Agrest (Axe) denominan líneas masculinas de cosmética.

Los adjetivos calificativos se convierten en instrumentos esenciales de estereotipia. Constituyen además unidades de preferencia en el lenguaje publicitario por su carga semántica. Hombres y mujeres son calificados de forma diferente en la publicidad, como lo son en la vida diaria. Un ejemplo lo encontramos también en las marcas de perfumes según sean femeninos o masculinos: ellas son bonitas (perfumes So Pretty de Cartier, o Beautiful de Stçe Lauder) y ellos egoístas (perfume É $\bar{g}$ oïste de Chanel).

Verbos y adverbios no son en sí mismos estereotipadores, pero la adscripción de acciones distintas a diferentes grupos sociales sí constituye una 
manera de estereotipar. El verbo designa la actividad, sin embargo, la publicidad parece diferenciar los verbos activos de los pasivos, según el actor sea hombre o mujer. En general, las acciones pasivas son asignadas con mayor frecuencia a las mujeres: soñar, esperar...; y las activas a los hombres: conducir, trabajar...

\subsection{Codificación escritural}

El profesor Raúl Eguizábal (2001: 81), en su tesis sobre el lenguaje publicitario, sitúa, a caballo entre lo verbal y lo visual, el código escritural. Las tipografías, las letras manuscritas o los rótulos también pueden ser elementos estereotipadores. Por lo que concierne a la estereotipia de género, existen grafías típicamente masculinas y grafías típicamente femeninas. La escritura de varón será angulosa, presionada y sencilla, mientras que la de la mujer será curvilínea y con adornos (Simón, 1994). Cuando en el anuncio se imitan grafías manuales, a menudo se conjugan estas asociaciones entre letra y género, que obviamente estereotipan. Del mismo modo, una grafía puede indicar la edad del autor, así como el nivel educacional e incluso la nacionalidad y el nivel social. La campaña de Dewar's White Label (figs. 1 y 2) introduce diferencias en las grafías de los personajes femeninos y masculinos, quienes, supuestamente, manuscriben los testimonios.

\subsection{Codificación cromática}

Los colores transportan todo un catálogo de significaciones simbólicas. En muchos casos funcionan como símbolos de cualidades típicamente femeninas o masculinas. Algunos colores se asocian más frecuentemente a la mujer y otros al hombre. En este sentido, la vieja identificación de lo masculino con el azul y de lo femenino con los rojizos y rosáceos sigue funcionando en la publicidad (perfumes Red Jeans y Blue Jeans, de Gianni Versace). Ocurre también que un mismo color adquiere significados diferentes según se adscriba a un hombre o a una mujer. Por ejemplo, el blanco puede ser pureza y sencillez en la mujer, mientras que en el hombre puede ser estabilidad o divinidad. Raúl Eguizábal (2001: 78) explica que la interpretación de los colores depende de factores sociales, culturales y psicológicos y que la selección cromática en publicidad debe perseguir un sentido inequívoco. Esto explica su condición de vehículos de estereotipia de género. La tabla siguiente divide algunos de los significados masculinos y femeninos de los colores. 

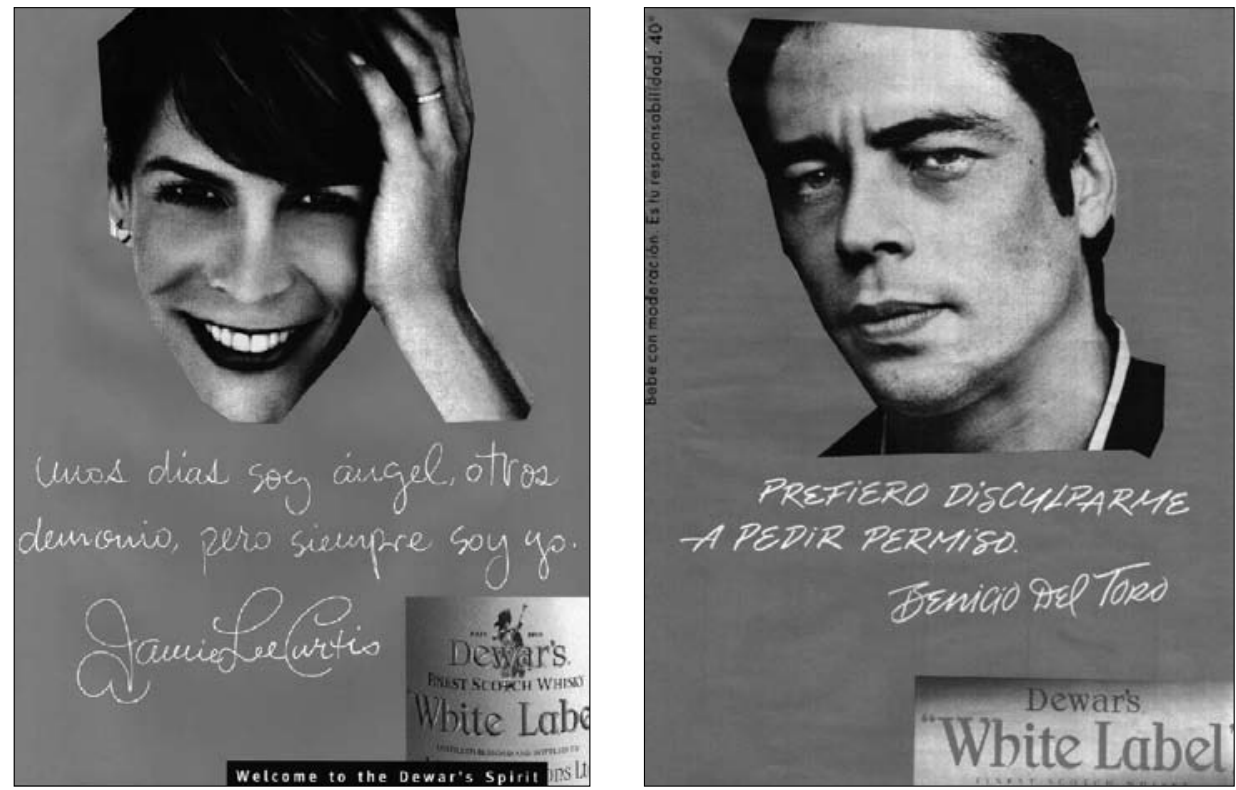

Figuras 1-2. Distinguir la grafía angulosa como típicamente masculina, al contrario que la escritura redondeada como propia de la mujer, es rasgo de estereotipia de género.

\begin{tabular}{|l|l|l|}
\hline \multicolumn{1}{|c|}{ Color } & \multicolumn{1}{|c|}{ Mujer } & \multicolumn{1}{c|}{ Varón } \\
\hline Rojo & Seducción, pasión & Fuerza, acción, peligro, triunfo \\
\hline Azul & Armonía, amor & Amistad, masculinidad \\
\hline Verde & $\begin{array}{l}\text { Deseo, juventud, naturaleza, } \\
\text { equilibrio, descanso }\end{array}$ & Ídem \\
\hline Blanco & $\begin{array}{l}\text { Pureza, sencillez, inocencia, } \\
\text { infancia, calma, armonía }\end{array}$ & Divinidad, estabilidad \\
\hline Negro & Noche, tristeza, pesar & Seriedad, nobleza, fuerza \\
\hline Gris & $\begin{array}{l}\text { Vejez, desánimo, desconsuelo, } \\
\text { aburrimiento }\end{array}$ & $\begin{array}{l}\text { Futuro, masculinidad, } \\
\text { tecnología, aburrimiento }\end{array}$ \\
\hline Ocre & $\begin{array}{l}\text { Naturaleza } \\
\text { Nobleza, fuerza, resistencia, } \\
\text { vigor, cordialidad, calidez }\end{array}$ \\
\hline Amarillo & $\begin{array}{l}\text { Envidia, adolescencia, risa, } \\
\text { placer, celos }\end{array}$ & Egoísmo, placer \\
\hline
\end{tabular}




\subsection{Codificación fotográfica}

Tanto las técnicas selectivas de los planos como las técnicas enfáticas de los mismos pueden ser utilizadas para estereotipar. Los retoques fotográficos para embellecer el aspecto de los modelos, o para resaltar alguno de sus rasgos, contribuyen a ofrecer una visión de género estereotipada. También es frecuente la manipulación de la escala dimensional o volumétrica de las personas, manipulación que difiere en el tratamiento de hombres y mujeres. Las fotografías de muchas mujeres son retocadas para estilizar sus figuras, constituyendo deformaciones fotográficas de cariz estereotipador (fig. 3). El hecho de que los primeros planos sean más abundantes en las representaciones de mujeres que en las de hombres es otra forma de estereotipia de género a través de este código.

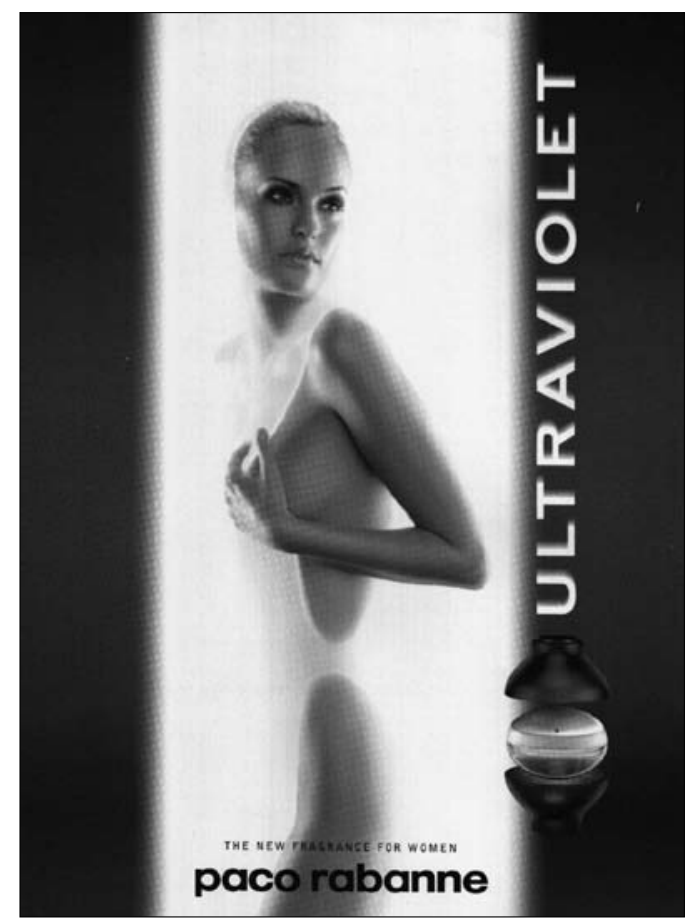

Figura 3. El codigo fotográfico introduce variaciones en el cuerpo femenino, adelgazándolo y estilizándolo, en una interpretación visual estereotipada. 


\subsection{Codificación morfológica}

Las figuras de las personas son utilizadas, en ocasiones, para dirigir la lectura de los anuncios. Puede esta rutina estereotipar las visiones de la mujer y del hombre, igualmente. En el ejemplo de la promoción del periódico El Mundo y la revista Sports Illustrated (fig. 4), se ha colocado un cuerpo de

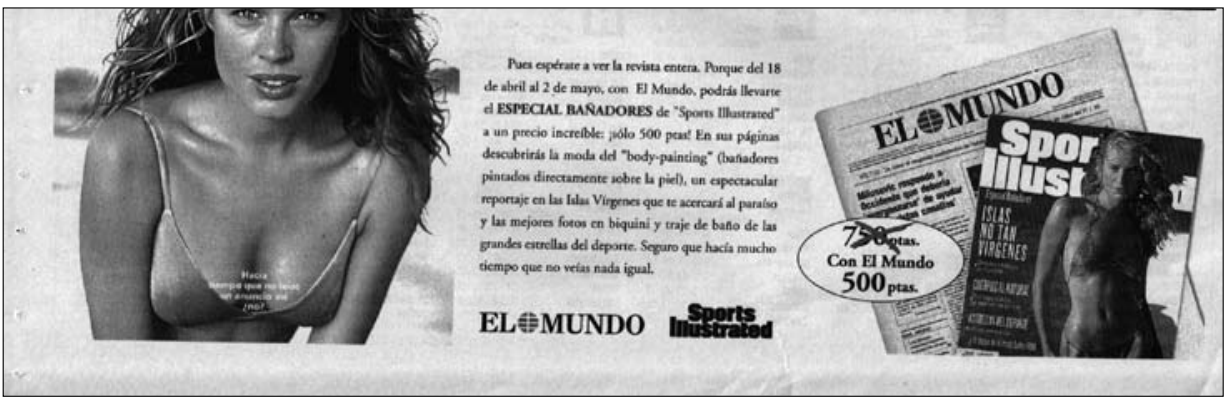

Figura 4. El código morfológico también puede guiarse con un diferente tratamiento entre hombres y mujeres. La ubicación del texto de la izquierda considera el busto de la mujer como un elemento de direccionalidad de la mirada.

texto delante del escote de la modelo. La frecuente utilización de desnudos femeninos para dirigir la atención hacia un mensaje publicitario es una práctica de estereotipia porque confunde a las mujeres con cuerpos, erotizándolas. Dentro de los clásicos ejes de lectura occidental, de arriba abajo y de izquierda a derecha, el anuncio de los perfumes Dupont (fig. 5) sustituye cualquier otro elemento de señalética o direccionalidad interna en el anuncio por el propio cuerpo

Figura 5. Como elemento de señalización para dirigir la mirada hacia el producto, en este anuncio se ha utilizado el escote de la mujer, a modo de flecha.

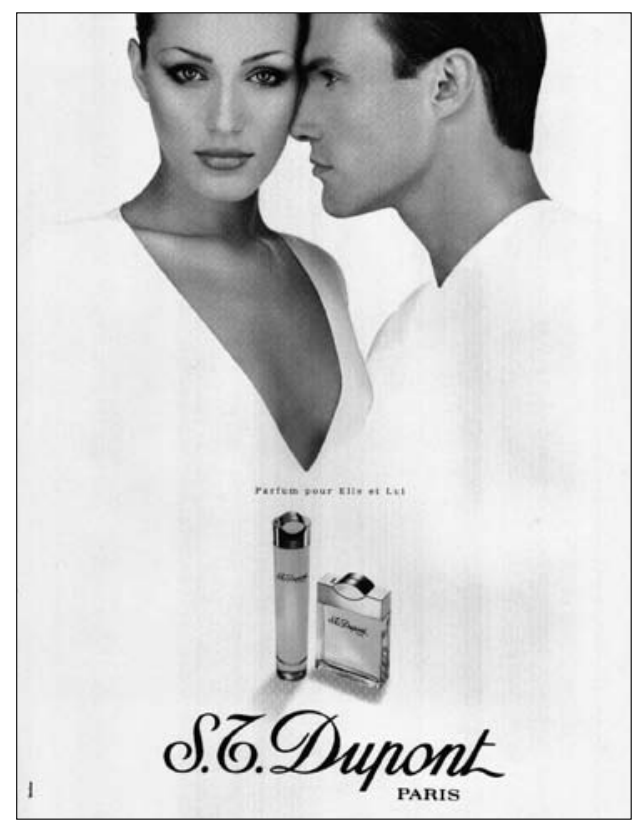


de las figuras: la lectura del anuncio se iniciará por la mujer, como suele ser habitual, si hay dos personas de distinto sexo; la mirada del hombre también nos dirige hacia ella. Entrando por los ojos de la mujer, nuestra mirada recorrerá su cuerpo y la forma de su escote emula una flecha que nos dirige al eslogan y las ilustraciones del producto.

\subsection{Codificación sociocultural y de la representación de las personas}

La representación de las personas en los anuncios responde también a la conjugación de una serie de elementos que proceden de distintas codificaciones. La profesora M. ${ }^{a}$ Cruz Alvarado ${ }^{3}$ analiza los estereotipos sociales desde el código sociocultural, el cual cuenta con sus propios elementos como la moda o la asignación de roles, y que - como considera Alvarado- es un código que planea por encima de los demás. Se esquematizan en la tabla siguiente, mediante la inclusión de algunos ejemplos, distintas dicotomías típicas que diferencian a hombres de mujeres, lo masculino y lo femenino, según las variantes de la codificación sociocultural del mensaje.

En estas codificaciones se funden lo físico y lo sociocultural, de modo que códigos como el gestual, por ejemplo, varían según el lugar geográfico y el momento histórico. Dos hombres paseando cogidos de la mano indica homosexualidad en Europa; sin embargo, el mismo gesto lo realizarán con naturalidad dos amigos árabes y sólo significará amistad entre ellos.

Las tablas siguientes dividen algunas adscripciones diferenciales entre hombres y mujeres de uso frecuente, observadas en numerosos estudios (Goffman, 1976; Peña-Marín y Frabetti, 1990; Martín Serrano, 1995...).

\section{ASPECTO}

\begin{tabular}{|l|l|}
\hline \multicolumn{1}{|c|}{ Mujer } & \multicolumn{1}{c|}{ Varón } \\
\hline Rubia & Moreno \\
\hline Joven, adolescente & Joven, maduro \\
\hline Delgada, débil & Fuerte, robusto \\
\hline
\end{tabular}

${ }^{3}$ Profesora de Lenguaje Publicitario en la Universidad de Valladolid. Modelo inédito de análisis, comentado con la autora en diversas conversaciones. En su opinión, el estereotipo transmitido por el anuncio puede efectivamente considerarse un caso de simbolización del lenguaje publicitario. 


\section{GESTO}

\begin{tabular}{|l|l|}
\hline \multicolumn{1}{|c|}{ Mujer } & \multicolumn{1}{c|}{ Varón } \\
\hline Expresividad & Inexpresividad \\
\hline Sonrisa, risa & Gesto serio, sonrisa contenida \\
\hline Es observada & Observa \\
\hline Gestos delicados, sensuales & Gestos duros, agresivos \\
\hline Sueña, está ausente & Vive, participa en una experiencia \\
\hline
\end{tabular}

\section{ASIGNACIÓN DE OBJETOS}

\begin{tabular}{|l|l|}
\hline \multicolumn{1}{|c|}{ Mujer } & \multicolumn{1}{c|}{ Varón } \\
\hline De moda y belleza & De profesión y hobbies \\
\hline Desnuda & Vestido \\
\hline Flores & Automóvil \\
\hline Utensilios del hogar y del cuidado de los hijos & Culturales: periódicos, libros \\
\hline
\end{tabular}

\section{ACCIONES QUE REALIZAN}

\begin{tabular}{|l|l|}
\hline \multicolumn{1}{|c|}{ Mujer } & \multicolumn{1}{c|}{ Varón } \\
\hline Inactiva, sin funciones de actividad asignadas & Activo \\
\hline Silenciosa & Ruidoso \\
\hline Modelo que posa & Actividad cotidiana \\
\hline
\end{tabular}

\section{ASIGNACIÓN DE ROLES}

\begin{tabular}{|l|l|}
\multicolumn{1}{|c|}{ Mujer } & \multicolumn{1}{c|}{ Varón } \\
\hline Madre. Cuidado de los niños & Padre. Juega con los niños, enseña \\
\hline Ama de casa & Profesional \\
\hline Compañera, acompaña & Protagonista, conduce, dirige \\
\hline
\end{tabular}


POSTURA Y POSICIÓN

\begin{tabular}{|l|l|}
\hline \multicolumn{1}{|c|}{ Mujer } & \multicolumn{1}{c|}{ Varón } \\
\hline Detrás del hombre & Delante de la mujer \\
\hline $\begin{array}{l}\text { Abajo, posición inferior, denotando } \\
\text { sumisión }\end{array}$ & $\begin{array}{l}\text { Arriba, posición superior, } \\
\text { denotando un papel dominante }\end{array}$ \\
\hline Al lado del hombre & Posición central \\
\hline
\end{tabular}

ENTORNO EN QUE SE UBICAN

\begin{tabular}{|l|l|}
\hline \multicolumn{1}{|c|}{ Mujer } & \multicolumn{1}{c|}{ Varón } \\
\hline Espacios privados, de la intimidad & $\begin{array}{l}\text { Espacios públicos, de la } \\
\text { sociabilidad }\end{array}$ \\
\hline
\end{tabular}

\section{LA CONSTRUCCIÓN SEMÁNTICA DEL ESTEREOTIPO PUBLICITARIO. EL EJEMPLO DEL SUJETO-OBJETO O LA COSIFICACIÓN PUBLICITARIA DE LAS PERSONAS}

La explicación del estereotipo publicitario como signo requiere una mirada a sus dimensiones estructural, semántica y pragmática. Como ejemplo de la construcción de significado que se produce en los estereotipos publicitarios se muestra aquí el paradigma del sujeto-objeto. Se trazan, a continuación, los parámetros de la objetivación de las personas, ya que uno de los principales juegos creativos de la publicidad consiste en equiparar objetos y sujetos.

La asociación de cualidades materiales a individuos configura un estereotipo especialmente característico de la publicidad. Esta objetivación se produce de muy distintas formas, tanto cuando se trata de la figura de la mujer como la del hombre, pero la estereotipia de género se introduce en la cosificación publicitaria en la medida en que la objetivación sexual o erótica se realiza de manera mucho más frecuente con la figura femenina que con la masculina.

En principio, pueden establecerse dos clasificaciones básicas de la objetivación: según se trate de una objetivación sexual o no sexual —si bien en este estudio se prefiere la denominación objetivación erótica - y según se realice una objetivación de forma visual o verbal. Pero no se trata de clasificaciones excluyentes, ya que pueden producirse todo tipo de combinaciones y de hecho suelen complementarse. 


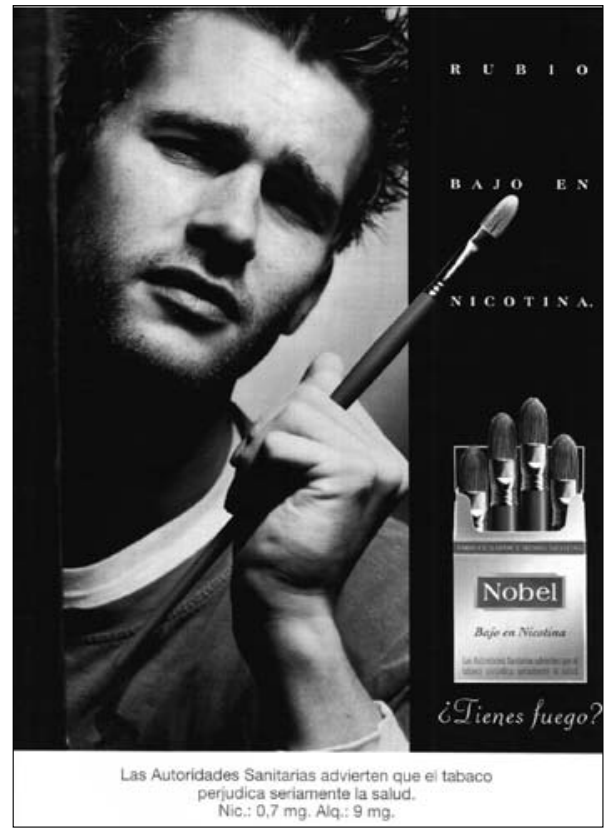

Figura 6. Los originales de los anuncios de Nobel estereotipan a través de la asignación de objetos.

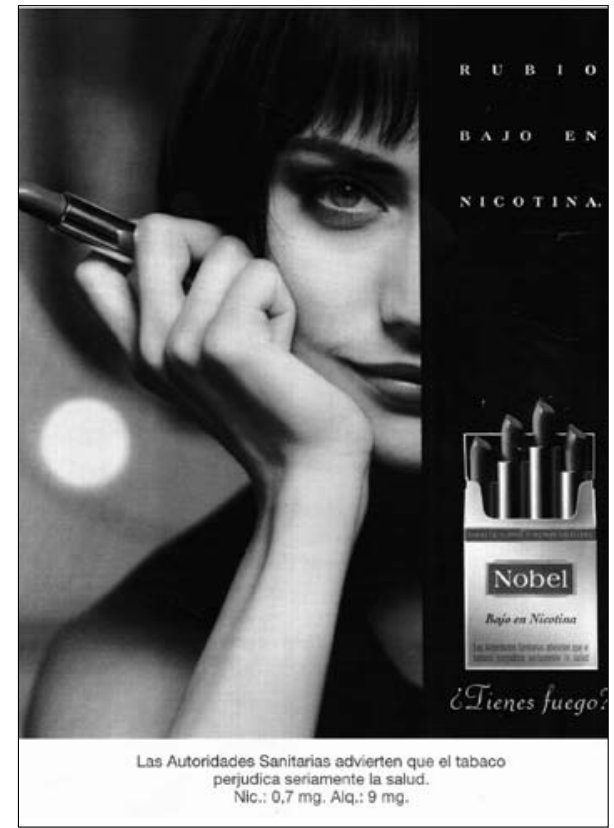

Figura 7. En sustitución del cigarrillo, el hombre aparece con un pincel, mientras la mujer lo hace con un lápiz de labios.

Personas como objetos y objetos como personas (figs. 6 y 7). Objetivación junto a subjetivación, antropomorfismo. Se trata de una figura retórica. Al hablar de los sentimientos de los objetos y de las cualidades materiales de las personas se produce una metáfora, el tipo de asociación de preferencia publicitaria. La metáfora como término y concepto se le atribuye a Artistóteles, quien dijo (según Ferrer, 1994: 155):

Saber encontrar bellas metáforas significa saber encontrar las semejanzas entre las cosas... La percepción de una semejanza, entre dos ideas, es la clave de la metáfora.

También Borges concebía la metáfora como una conexión íntima entre una imagen y otra (op. cit.: 156). Y esa conexión es el juego que el publicitario propone al lector, descubrir la semejanza, comprenderla, descifrarla, porque, como dice Péninou (1976: 119), la importancia de la metáfora está en su lectura: 
Ingenua o pensada, elemental o rebuscada, la metáfora es expresión de una determinada visión en la que la importancia está, no en la cosa mirada, sino en la mirada misma.

La objetivación publicitaria suele estar basada en dos relaciones de la retórica clásica: la similitud y el contraste, subformas de la adjunción o adiecto y la sustitución o inmutatio. El símil de las formas o los contenidos de objeto y persona, o bien, producto y consumidor, se encuentra implícito en una enorme cantidad de anuncios. La comparación - manifestación de la relación de contraste- entre ambos también es especialmente habitual. El titular del anuncio de Ron Barceló expone: Este oscuro objeto de deseo refiriéndose tanto al licor como a la joven representada, comparándolos; otros anuncios presentan los productos con la coletilla como tú para referirse al producto.

La sustitución como forma de objetivación publicitaria puede ejemplificarse con el anuncio de Campari, donde el vermouth ha sido sustituido por los labios de una mujer (fig. 8) o con el original del perfume Gentleman de Givenchy (fig. 9), en el que la figura del hombre ha sido sustituida por el

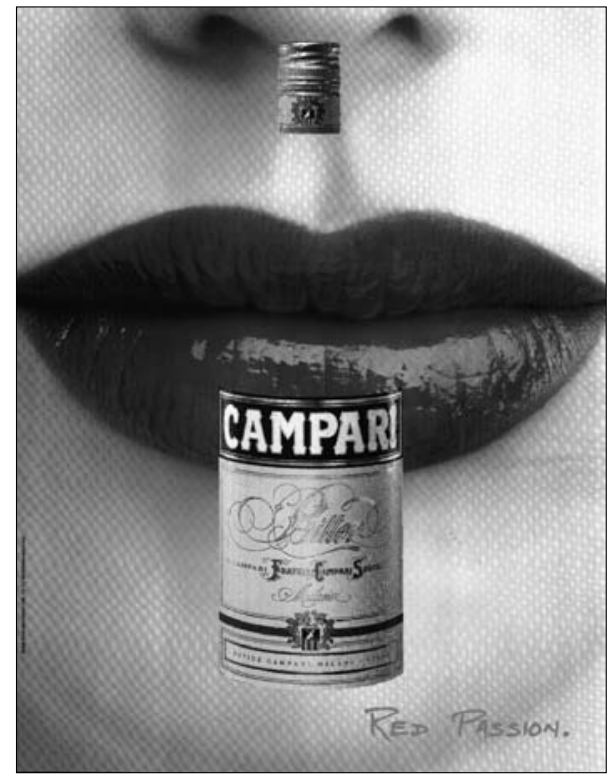

Figura 8. La objetivación en este caso se activa mediante recursos de retórica visual como la sustitución (inmutatio) del producto por los labios de la modelo.

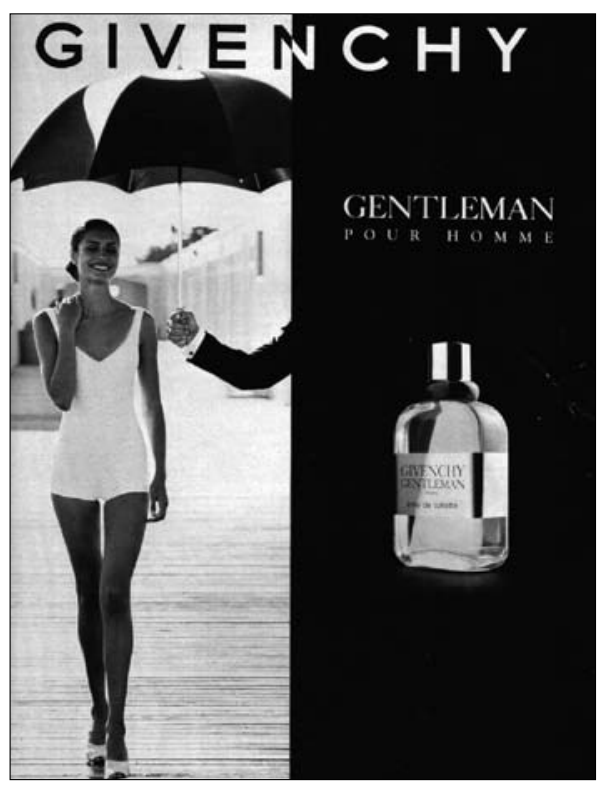

Figura 9. Sustitución de persona por frasco de perfume. 
frasco de perfume. La sustitución - explica González Martín (op. cit.: 275)— es una forma de supresión o retractio, seguida de una adjunción o adjecto. En el ejemplo del anuncio para Chaumet Spirit (fig. 10) se conjugan ambas relaciones: el símil visual entre producto y persona y la sustitución de la persona por el producto, en el plano inferior.

Entre la adjunción y la sustitución, a través de los códigos visual y/o verbal y con propósitos de objetivación erótica o sin ellos, se mueve el universo de la objetivación publicitaria.

El fondo de esta objetivación publicitaria no es la cosa, como objeto resultante, sino el trasfondo, la idea. Desde el empirismo inglés, George Berkeley prefería la palabra idea a la palabra cosa (según indica Ferrer, 1994:

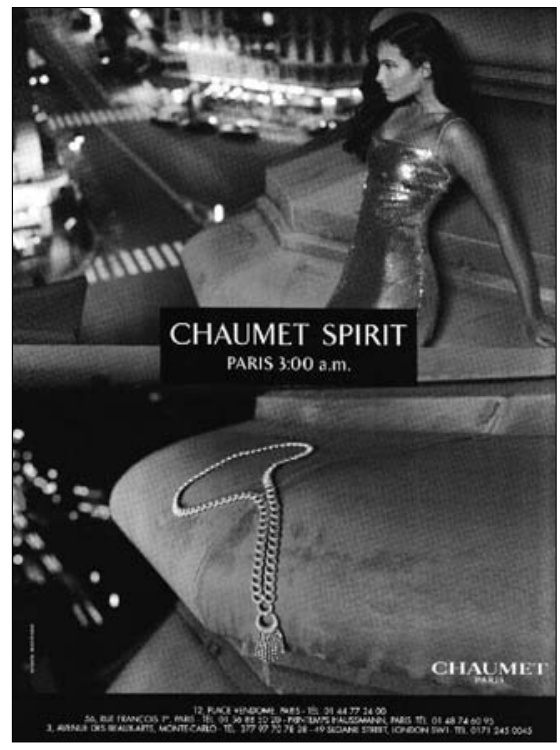

Figura 10. Simil y sustitución para confundir persona y producto anunciado. 64). Este filósofo irlandés concebía la idea $^{4}$ «como la cosa percibida ya que todo es representación en su interpretación del mundo: no existen cosas con independencia del espíritu que las percibe» (Berkeley, 1968: 12). Esa idea sería el contenido del estereotipo.

La idea, en su origen griego, se refería al ideal, la imagen perfecta. Y por esta consecución lógica, la idea de esta práctica tan habitual en el mensaje publicitario es probablemente la imagen perfecta. El equilibrio entre persona y producto, la equiparación perfectamente nivelada. Ése es el ideal publicitario del consumo. En la cosificación hay estereotipo, pero también arquetipo publicitario.

A continuación se comentan algunas de las frecuentes vías de cosificación que se encuentran en los mensajes de los anuncios.

${ }^{4}$ Según el profesor de Filosofía del Instituto Andrés Laguna de Segovia, y de Teoría de la Imagen en la Universidad de Valladolid, Rodrigo González Martín, la ruptura del concepto de materia, en favor del concepto de idea, es uno de los principales hallazgos de toda la filosofía moderna. Véase también J. O. Ursom (1984). Berkeley. Madrid: Alianza; J. Berkeley (1923). Tres diálogos entre Hilas y Filonús. Madrid: Calpe; J. Berkeley (1965). Ensayo de una nueva teoría de la visión. Buenos Aires: Aguilar. 


\subsection{La semejanza de forma o contenido}

El estudio del símil visual o verbal en los anuncios es objeto de la retórica publicitaria. Se trata de una de las figuras más utilizadas para la consecución de la objetivación publicitaria. Si se propone verbalmente, la semejanza se realizará a través de una comparación o símil retórico. Si se trata de un símil visual, éste se realizará a través de los elementos básicos de la codificación visual, como se explica a continuación.

Elementos simples como el tratamiento de los contornos se utilizan para cosificar a los sujetos. El diseño de envases y productos los asemeja en ocasiones a las personas. Los contornos conjugan en este caso la vía de cosificación. Los frascos de perfumes de Jean Paul Gaultier (fig. 11) o la semejanza entre el frasco del perfume Gala de Loewe y las Meninas de Velázquez son algunos de los ejemplos. En el caso del perfume Champagne (fig. 12) la modelo adopta forma de la letra griega, símbolo tipográfico de Yves Saint Laurent.

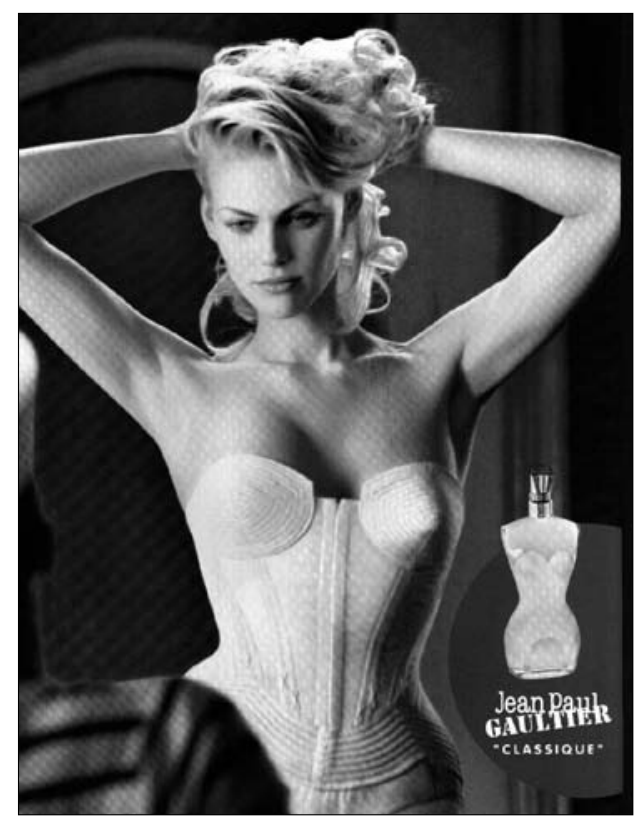

Figura 11. Objeto y mujer, hechos a imagen y semejanza, el uno del otro.

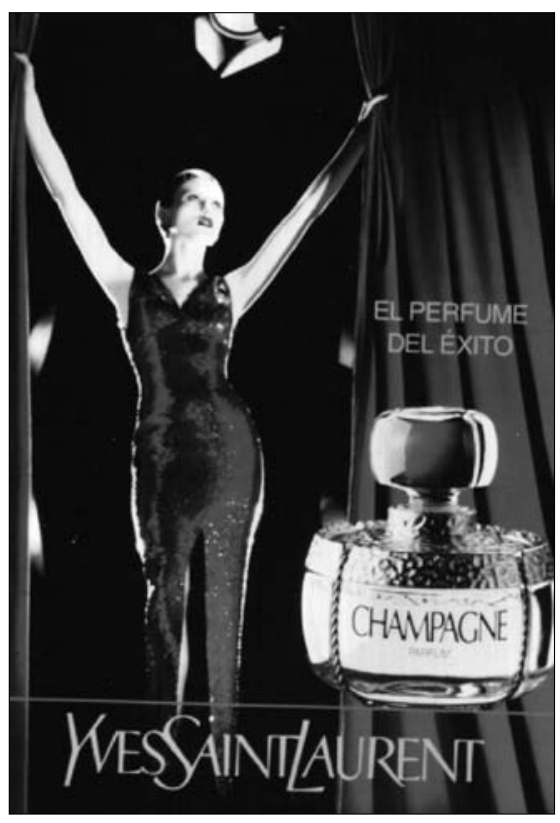

Figura 12. La mujer se convierte en la letra Y, símbolo de la marca. 
Elementos cualitativos como el tratamiento del color y las texturas sirve igualmente para encontrar la semejanza de formas. En ocasiones se introduce un filtro de color que confunde ambas representaciones. También el tratamiento de las texturas puede asemejarse, como en el caso del anuncio de Montana (fig. 13), en el que la modelo adquiere una textura y color casi metálicos, además su postura imita la forma del frasco de perfume y la palma de su mano, con la $M$ de las líneas marcadas de su mano izquierda, se muestra como la inicial de Montana.

Elementos relacionantes como la escala, la simetría y la perspectiva, son conjugados para asemejar el producto a la persona. Es ejemplo del juego de escalas con fines estereotipadores la minimización del tamaño de las personas con respecto al producto magnificado (fig. 14), lo cual suele hacerse más a menudo con las figuras de mujer que con las de hombre; se trata de una propuesta de mujer insignificante, cuya presencia queda reducida ante la magnitud de su cosas. La perspectiva también puede ser conjugada para fines

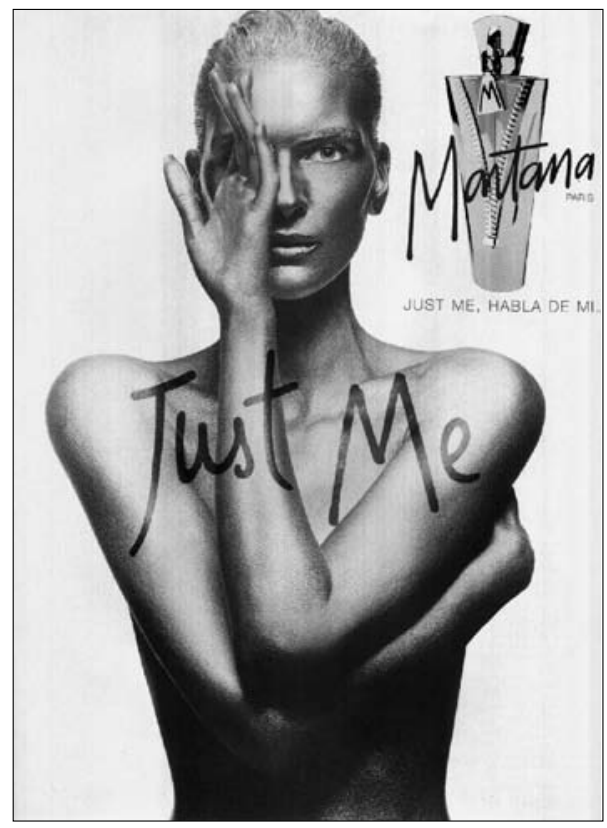

Figura 13. Mimetismo persona-producto.

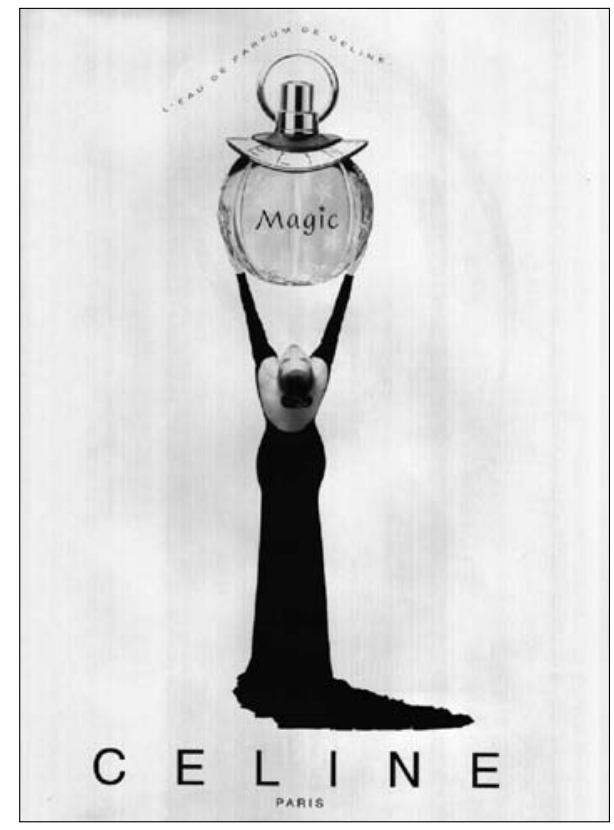

Figura 14. Alteración de las escalas y minimización de la persona respecto al producto como recurso de objetivación de las personas. 
similares. Un plano en picado de un producto puede transferirle cierta personalidad humana o cierta magnitud superior al hombre.

El caso de la simetría sugiere un análisis interesante. Un ejemplo de simetría objetivante se produce con los juegos de imágenes devueltas por el espejo puesto que se convierte en imagen. La presentación de la persona y su reflejo en el espejo presenta un nuevo caso de persona y objeto en un planteamiento de similitud, si bien es en este caso donde se encuentra la máxima semejanza o la identificación perfecta entre persona e imagen objetivada de la misma. La imagen reflejada ya no es una persona, sino un objeto con apariencia de persona, y en muchos casos el anuncio propone al lector que mire no a la persona, sino a la imagen que devuelve el espejo, que es la imagen que desea. La reflexión puede encontrarse no solamente en espejos, sino en los mismos productos (como la carrocería brillante de un automóvil, por ejemplo) y en la sombra, como lo hizo un famoso anuncio del perfume $\bar{E}$ goöste, reflexión simétrica en la que se vuelven a encontrar persona y cosa semejante, el hombre contra su imagen, donde de nuevo es el reflejo el que posee el producto y la persona real quien lo desea.

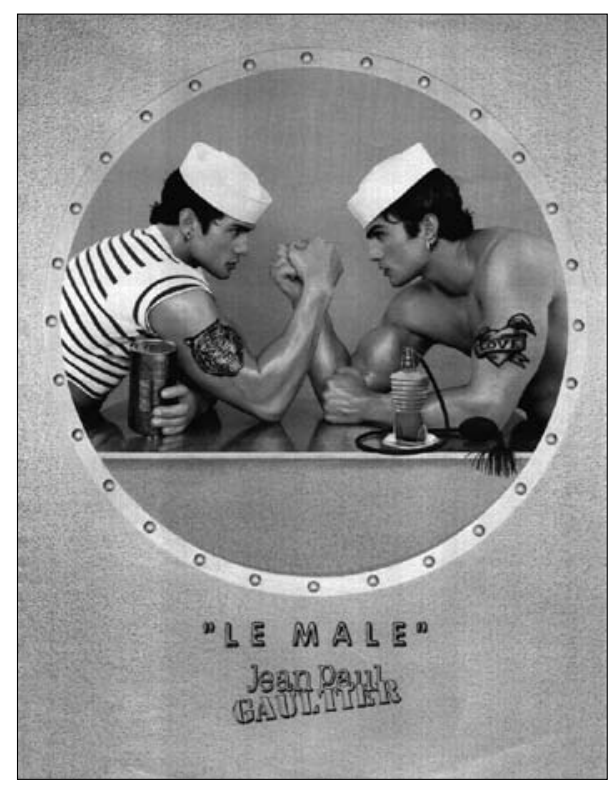

Figura 15. Contraposición de la persona consigo misma y personalización de producto en idénticas personas.

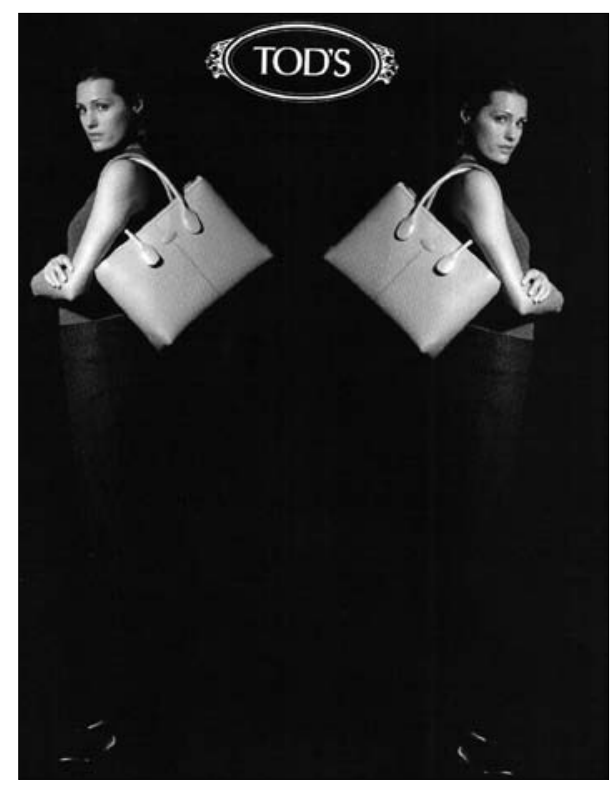

Figura 16. La duplicación de la figura la «desindividualiza», la convierte en objeto seriado. 
Pero la publicidad puede presentar simetrías perfectas sin necesidad de utilizar espejos ni superficies cristalinas, ya que los trucos de imagen permiten contraponer una imagen consigo misma (fig. 15), en un caso de simetría conseguida por duplicación. La multiplicación visual de la persona es otra de las formas de objetivar mediante elementos relacionantes de lo visual (fig. 16). Al duplicar la imagen de alguien, ésta se despersonaliza, porque cada persona es única y diferente a las demás, no existen dos idénticas. Se le transfieren así propiedades de los productos en serie, se le asemeja a un producto industrial sin diferencias con los fabricados en el mismo molde. Este caso de simetría participa, más que de la similitud entre persona y objeto, de la transferencia de cualidades materiales a las personas, un segundo nivel de objetivación publicitaria que se comenta a continuación.

\subsection{Personificación y prosopopeya}

La personificación es otra figura retórica de frecuente presencia en la publicidad. Se define como la «atribución a seres inanimados de rasgos propios de los animados» (Ferraz, 1996: 54). La otra cara de la figura sería la prosopopeya u objetivación de las personas en cuanto la «atribución a seres animados de rasgos propios de los inanimados». Son muy diversos los modos publicitarios de transferir cualidades personales a los objetos y cualidades de las cosas a las personas, que en definitiva intentan personificar a los objetos o bien objetivar a las personas. Algunos ejemplos son los siguientes:

Casos de personas envasadas o empaquetadas (fig. 17), así como etiquetas o envases con personas representadas, por tanto también minimizadas y con la sugerencia de que el envase contiene a la persona, su esencia.

El marcaje de personas, como si de productos se tratase (fig. 18), sugiriendo no la pertenencia del producto a la persona, sino de la persona a la marca. La creación de productos con el nombre de personas, como el perfume Naomi Campbell.

Otra cara de la moneda viene presentada por la personificación de objetos. Objetos que hablan, piensan o sienten. Personificar los objetos suele implicar la masculinización o feminización de los mismos, y esa identificación es una forma de estereotipar a las personas. La propia creación de las marcas publicitarias suele consistir en dotar de una personalidad definida, identificable y única a los productos. En este sentido marcar es personificar. Pero el trabajo publicitario de la personificación de las cosas va más allá de la simple concesión de personalidad o de habilidades de las personas a las cosas, 


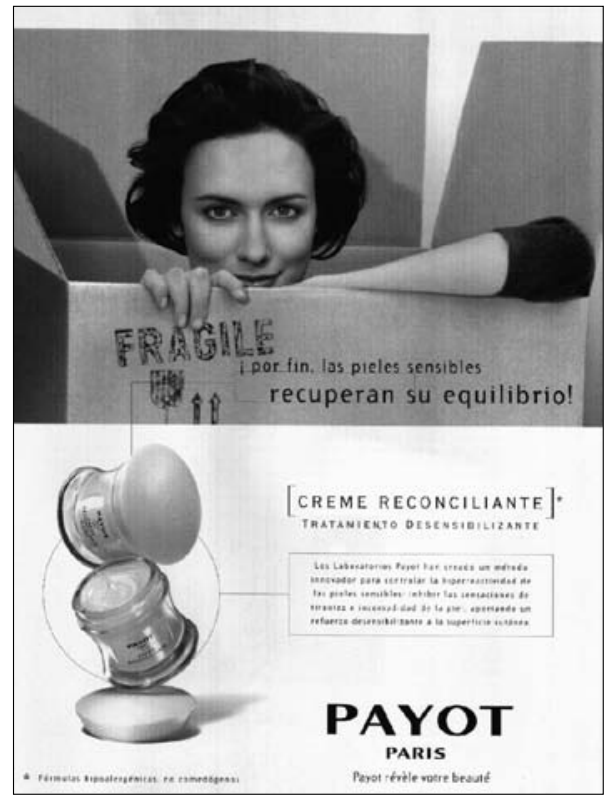

Figura 17. No sólo se empaquetan productos, sino también personas.

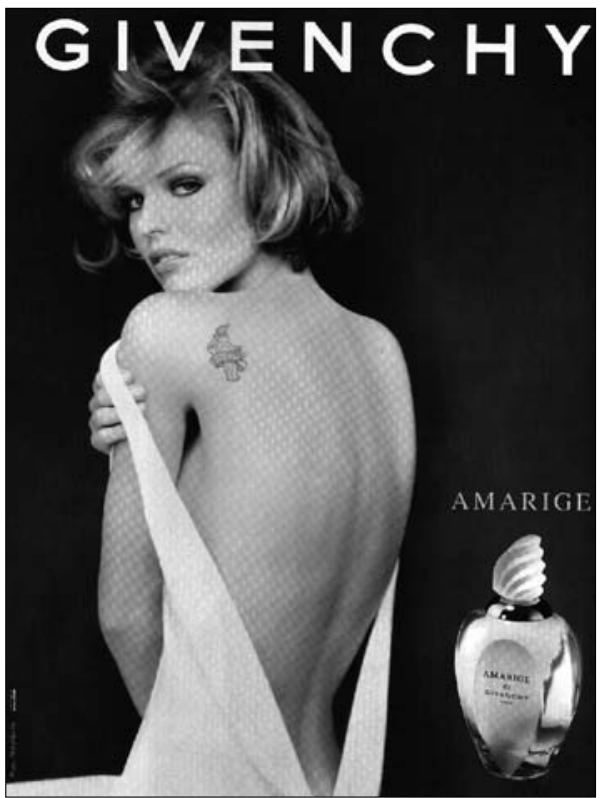

Figura 18. Persona marcada cual mercancía.

como puede verse en el ejemplo de René Manzini (fig. 19) el bolso publicitado aparece anunciado en semejanza con un órgano interno del humano, probablemente un hígado. Se le reconoce al producto además una belleza de color y forma que no se le reconocería al propio órgano. A la vez, la necesidad de tener el producto se equipara a la necesidad de contar con el órgano vital. El hombre Martini era una personificación del producto, y Evax personifica la menstruación en una mujer vestida de rojo.

La fusión visual entre producto y objeto alcanzaría un grado muy elevado en la similitud y objetivación. Pirelli propone de esta forma atletas con pies de caucho y Bucheron consigue que su perfume sean las lágrimas de una mujer (fig. 20). Diferentes casos de metamorfosis son habituales en los anuncios.

La identificación de la persona con el producto, a partir de sus propiedades simbólicas, alcanza muchas veces la objetivación. Como sucede con el eslogan de la marca de relojes suizos Swatch es I want to be Swatch ${ }^{2}$.

${ }^{5}$ En el catálogo de la colección otoño-invierno la presentación terminaba de explicar el eslogan: «I WANT TO BE... part of the irresistible look of Swatch» (Swatch, 2001: 1). 


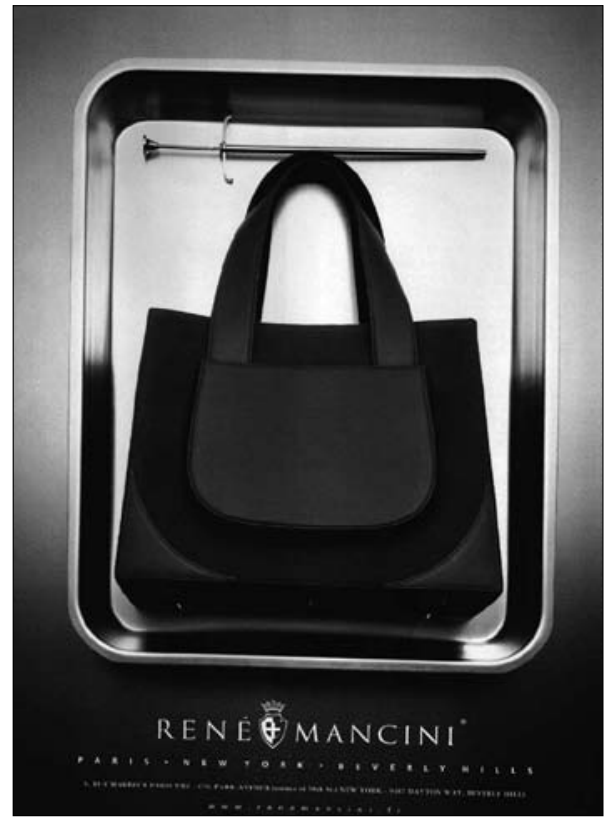

Figura 19. ¿Objeto de consumo u órgano vital? Caso de personificación de los objetos.

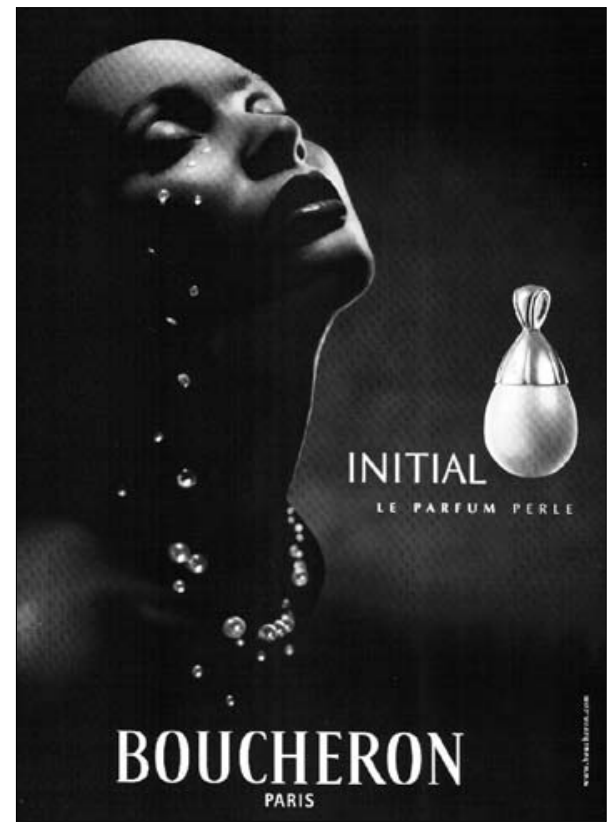

Figura 20. Las perlas anunciadas son lágrimas de mujer.

\subsection{Asociación de personas y productos}

Este ámbito de la asociación se refiere al de la creación publicitaria de relaciones entre productos y personas y la relación, como dice González (op. cit.: 276) es causa de todo funcionamiento metonímico, de modo que si al estudiar el símil se exploraron metáforas publicitarias, ahora, al estudiar la relación, se explorará la metonimia publicitaria.

Cuando se pretende identificar una marca o producto con una persona se intenta generar una asociación mental de ambos. Esa vinculación indisoluble es la que intenta buscar el patrocinio deportivo entre deportista y marca. Es una forma de marcar la persona a la vez que de asociar rasgos de personalidad al producto. Cuando las emisiones publicitarias son reiteradas, esa asociación puede sedimentar de forma cognitiva, de modo que Viceroy sea relacionado con Julio Iglesias, como Diávolo a Antonio Banderas y Citroën Xara a Claudia Schiffer. La metonimia del lenguaje publicitario tiene por objetivo entonces, una asociación cognitiva en la mente del receptor. 
Refiriéndonos a la categoría de objeto erótico, se observa que la expresión objeto sexual ha sido utilizada de forma extensiva y se ha dilatado su sentido. Objetivar sexualmente a una persona implica desconsiderar sus cualidades como persona y tratarla únicamente como medio de satisfacción sexual. La publicidad no suele hacer esto con la representación de sus modelos. En la publicidad no suelen presentarse escenas de sexo explícito, como sí se encuentran a menudo en el cine o en la literatura, por ejemplo, de modo que sexo no es un vocablo apropiado para hablar de la persuasión erótica de los anuncios.

En realidad, el término sexual es inadecuado para hablar de representaciones mediáticas. Explica Octavio Paz (según Ferrer, 1994: 335) que la gente confunde el erotismo con la sexualidad. El sexo tiene una naturaleza biológica, mientras que el erotismo es una cuestión social, y por tanto es este término el que puede adaptarse mejor al ámbito de los medios de comunicación social. El escritor definía el erotismo como una metáfora de la sexualidad y en líneas anteriores ha sido ya comentado que la objetivación publicitaria es una metáfora. Si la sexualidad es acto, el erotismo es imaginación. La publicidad pretende estimular la imaginación, por algo se la define como fábrica de ilusiones.

Entre la persona representada en el anuncio y el receptor del mensaje no hay sexo, aunque sí puede haber incitación erótica. Por esta razón, en este artículo se adopta la expresión objeto erótico frente a la extendida locución $o b$ jeto sexual, cuya distorsión y generalización ha estado provocada por el uso que del mismo se ha hecho, sobre todo, desde posturas feministas.

Puede establecerse una gradación en los distintos niveles de objetivación erótica. Se presentan y ejemplifican a continuación, de mayor a menor grado de objetivación y erotización.

En primer lugar, puede hablarse de objeto erótico propiamente dicho. En este nivel la persona no tiene más función que incitar el deseo sexual. El grado de erotismo es máximo. La persona representada puede adoptar posturas provocativas e insultantes, aparecer desnuda o semidesnuda sin ninguna justificación con relación al producto, simplemente para llamar la atención. En muchos casos de objetivación erótica no se muestran los rostros de las personas, de forma que la persona sea cuerpo, es decir, algo en vez de alguien. También es objeto erótico el provocar de forma erótica al receptor. Un anuncio de ropa interior, por ejemplo, no tiene por qué ser erótico en el tratamiento, pero un calendario con chicas desnudas o semidesnudas sí trata a esas modelos como objetos eróticos, al quedar injustificado el desnudo y al 
aparecer erotizados sus cuerpos y sus posturas.

Otra figura podría denominarse seductor, distinguiendo a la persona que tiene un papel activo (una mira$\mathrm{da}$, un gesto, una frase...) con el fin de embriagar al lector o insinuarse visual (fig. 21) o verbalmente. Es seductora la persona con vestimentas transparentes, cuerpos voluptuosos y erotizados sin otra justificación que la de servir de llamada de atención al sexo contrario.

Pueden denominarse objeto decorativo a los casos vulgarmente denominados como mujer florero. Se trata de las representaciones en que las personas sólo aparecen en el anuncio para adornar.

En la categoría de belleza física

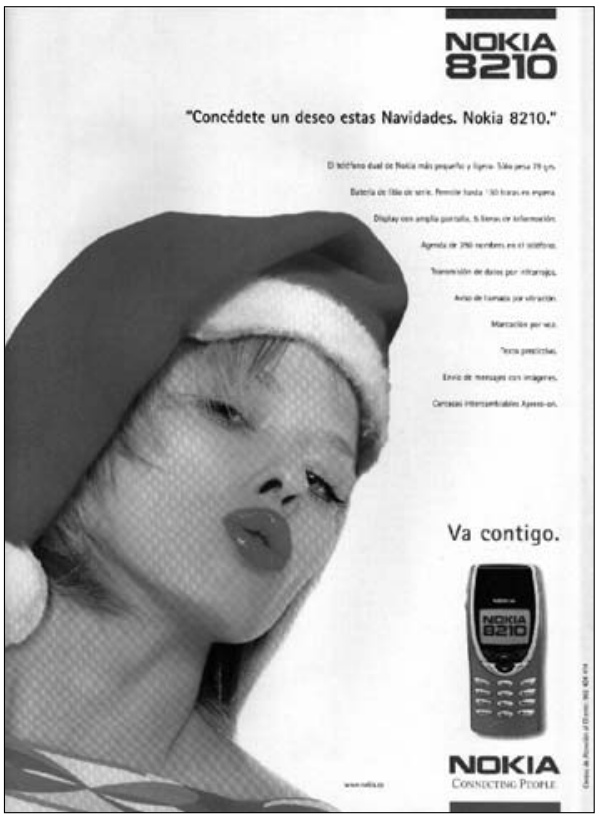

Figura 21. La figura seductora se insinúa, en este caso con un gesto. pueden ser contemplados los casos en que el modelo o la modelo del anuncio es elegido únicamente por su belleza o aquellos en que lo único que de esa persona se dice o muestra es la belleza física. Cuando se escoge a una persona para comunicar otros valores además de la belleza, cuando esa persona tiene un papel asignado en el relato, entonces no ha de considerarse como objetivada de manera erótica.

\section{PRAGMÁTICA DEL ESTEREOTIPO PUBLICITARIO}

La función pragmática del lenguaje publicitario es un condicionante básico de su estereotipia. A juicio de González Martín (1996: 287): «La acción comunicativa publicitaria suele coincidir con la reafirmación o con la transformación de un contexto». En efecto, el estereotipo publicitario reafirma y a la vez transforma su objeto de referencia, condicionado por su contexto.

Mediante los estereotipos, el emisor publicitario ejerce siempre una influencia racional, si bien puede influir, a la vez, de manera efectiva. Se trata de una influencia racional porque actúa sobre un conocimiento previo del 
receptor, confirmando o desmintiendo su visión estereotipada del grupo social. La influencia positiva o confirmadora del estereotipo suele producirse cuando el estereotipo cumple una función de fácil reconocimiento de la característica del grupo social que se expone. La influencia negativa que desmiente el estereotipo suele utilizarse como llamada de atención al receptor.

Pueden conjugarse también influencias afectivas. A menudo despierta en el receptor la esperanza de ciertas satisfacciones o el miedo a ciertas insatisfacciones, modo éste en que actúa la influencia afectiva, en términos de González Martín (op. cit.: 288) y según él mismo explica. Entrando en el caso de los estereotipos de género, éstos son condensados en muchos anuncios — a juicio de Barthel (1988) — con la promesa implícita de que el producto ayudará a alcanzar nuestra identidad de género. La motivación podrá ser también negativa y alimentar el temor de la insatisfacción experimentada por no conseguir el producto.

\section{REFERENCIAS BIBLIOGRÁFICAS}

BACA LaGos, V. (1995). «El análisis de las representaciones sociales de los géneros y los estudios de la mujer en España». En Martín Serrano et. al., 96-130.

Barthel, D. (1988). Putting on Appearances. Gender and Advertising. Philadelphia: Temple University Press.

Bernstein, H. R. (1975). «Ads Ignore Women, Use Stereotypes: Levine». Advertising Age, 16 de junio, 86.

Ceulemans, M. y Fauconnier, G. ( 1981). «Imagen, papel y condición de la mujer en los medios de comunicación social. Compilación y análisis de los medios de comunicación». Colección Estudios y Documentos de Comunicación Social, 84, París: UNESCO.

Cortese, A. y Joseph, P. (1999). Provocateur. Images of Women and Minorities in Advertising. Lanham, Maryland: Rowman \& Littlefield Publishers, Inc.

EguizÁbal MaZA, R. (2001). Fotografía publicitaria. Madrid: Cátedra.

- (1990). El análisis del mensaje publicitario. Tesis doctoral. Madrid: Universidad Complutense. 
Ferraz Martínez, A. (1996). El lenguaje de la publicidad. Madrid: Arco/Libros.

FERrer, E. (1994). El lenguaje de la publicidad. México: Fondo de Cultura Económica.

GALlagher, M. (1995). «Mujeres y hombres en los medios de comunicación». Revista de Ciencias de la Información, número extraordinario (Madrid: Editorial Universidad Complutense de Madrid), 71-112.

GonzÁlez MarTín, J. A. (1982). Fundamentos para la teoría del mensaje publicitario. Madrid: Forja.

- (1996). Teoría general de la publicidad. Madrid: Fondo de Cultura Económica.

LEÓN, J. L. (2001). Mitoanálisis de la publicidad. Barcelona: Ariel Comunicación.

MARMORI, G. (1977). Iconografía femenina y publicidad. Barcelona: Gustavo Gili, Punto y Línea.

Martín Serrano, M.; Martín Serrano, E. y Baca Lagos, V. (1995). Las mujeres y la publicidad. Nosotras y vosotros según nos ve la televisión. Madrid: Instituto de la Mujer, Ministerio de Asuntos Sociales.

PeIrCE, Ch. S. (1986). La ciencia de la semiótica. Buenos Aires: Ediciones Nueva Visión.

- (1987). Obra lógico semiótica. Madrid: Taurus.

PÉninou, G. (1976). Semiótica de la publicidad. Barcelona: Gustavo Gili.

PeÑa-Marín, C. y FrabetTi, C. (1990). La mujer en la publicidad, catálogo de la exposición con el mismo nombre. Madrid: Instituto de la Mujer.

R.A.E. (1992). Diccionario de la lengua española. Madrid: R.A.E./Espasa Calpe.

REY FuENTES, J. (1994). El hombre fingido. La representación de la masculinidad en el discurso publicitario. Madrid: Fundamentos.

SÁnChez Corral, L. (1997). Semiótica de la publicidad. Narración y discurso. Madrid: Síntesis.

Sebastián, J.; Alonso, F. et. al. (1985). «Análisis de los estereotipos sexuales en la publicidad impresa». Revista de Psicología General y Aplicada 40, vol. 6, 1.115-1.135. 
Simón, J. J. (1994). El gran libro de la grafología. Barcelona: Círculo de Lectores.

Tuchman, G.; Kaplan Daniels, A. y Benet, J. (eds.) (1978). Hearth \& Home. Images of Women in the Mass Media. New York: Oxford University Press. 